\title{
The Steel Industry in the European Union on the Crossroad to Carbon Lean Production-Status, Initiatives and Challenges
}

\author{
Monika Draxler ${ }^{1}$, Johannes Schenk ${ }^{1,2}$, Thomas Bürgler ${ }^{1,3}$, and Axel Sormann ${ }^{1}$ \\ ${ }^{1} \mathrm{~K} 1-\mathrm{MET} \mathrm{GmbH}$, Leoben, Austria \\ ${ }^{2}$ Chair of Ferrous Metallurgy, Montanuniversitaet Leoben, Leoben, Austria \\ ${ }^{3}$ voestalpine Stahl GmbH, Linz, Austria
}

Received February 28, 2020; accepted March 10, 2020; published online March 24, 2020

\begin{abstract}
The EU commission has committed to fulfil the targets of greenhouse gas (GHG) emission reduction in 2050 by $80 \%$ in comparison to the level of 1990 . The fulfilment of the EU's climate policies brings new challenges for the iron and steel industry. The European steel industry is forced to develop strategies for the transition of their technology to a carbon lean production and to keep the competitiveness in the world market. The steel companies in EU27 are taking the challenge to secure the steel production in Europe and have launched innovation projects for $\mathrm{CO}_{2}$ mitigation with the focus on the technological pathways Carbon Direct Avoidance (CDA) and Smart Carbon Usage (SCU), which are, beside Circular economy, defined as important pillars for $\mathrm{CO}_{2}$ abatement in European steel industry. The transformation of the steel industry must go hand in hand with a decarbonisation of the energy supply and other industries within EU27.
\end{abstract}

Keywords: $\mathrm{CO}_{2}$ emission, Carbon lean steel production, Hydrogen, Renewable energy

Die europäische Stahlindustrie im Wandel hin zu einer $\mathrm{CO}_{2}$ - armen Eisen- und Stahlproduktion: Entwicklungsstand, Initiativen und Herausforderungen

Zusammenfassung: Die Europäische Kommission hat sich verpflichtet, eine schrittweise Verringerung der Treibhausgasemissionen voranzutreiben und bis zum Jahr 2050 eine Senkung um $80 \%$ im Vergleich zum Level von 1990 umzusetzen. Die Eisen- und Stahlindustrie wird dadurch vor neue Herausforderungen gestellt und muss, um dieses Ziel

Univ.-Prof. Dipl.-Ing. Dr. techn. J. Schenk (ه)

Chair of Ferrous Metallurgy,

Montanuniversitaet Leoben,

Franz-Josef Straße 18,

8700 Leoben, Austria

johannes.schenk@unileoben.ac.at zu erreichen, unter gleichzeitigem Erhalt der Wettbewerbsfähigkeit am Weltmarkt seine Verfahren kohlenstoffarm gestalten. Durch innovative Projekte bzw. Technologien soll eine Reduktion der $\mathrm{CO}_{2}$-Emissionen der europäischen Stahlindustrie realisiert werden. Neben der Kreislaufwirtschaft liegt der Fokus dabei vor allem auf den beiden Technologiepfaden Carbon Direct Avoidance (CDA) und Smart Carbon Usage (SCU). Zusätzlich zur Technologieverbesserung und -entwicklung in der Stahlindustrie ist die Dekarbonisierung des Energieversorgungsnetzes sowie weiterer anderer Sektoren essenziell.

Schlüsselwörter: $\mathrm{CO}_{2}$-Emissionen, Kohlenstoffarme Stahlproduktion, Wasserstoff, Erneuerbare Energie

\section{Introduction}

The European steel industry is the second largest steel producer worldwide generating 168 million tons of steel at more than 500 production sites across $24 \mathrm{EU}$ member states in 2018 [1]. Steel production is either based on iron ore or scrap, whereby the shares of the individual routes differ significantly depending on regional circumstances. The current available crude steel production routes are shown in Fig. 1.

The two predominant steel production routes in EU27 are

- (I) the integrated blast furnace/basic oxygen furnace (BF/BOF) route, where the steel is produced from virgin iron ore with $\mathrm{BF}$ including sintering, cokemaking and BOF for crude steel production, and

- (II) the electric arc furnace (EAF) scrap route, where the steel is produced by recycling of scrap in the EAF. 


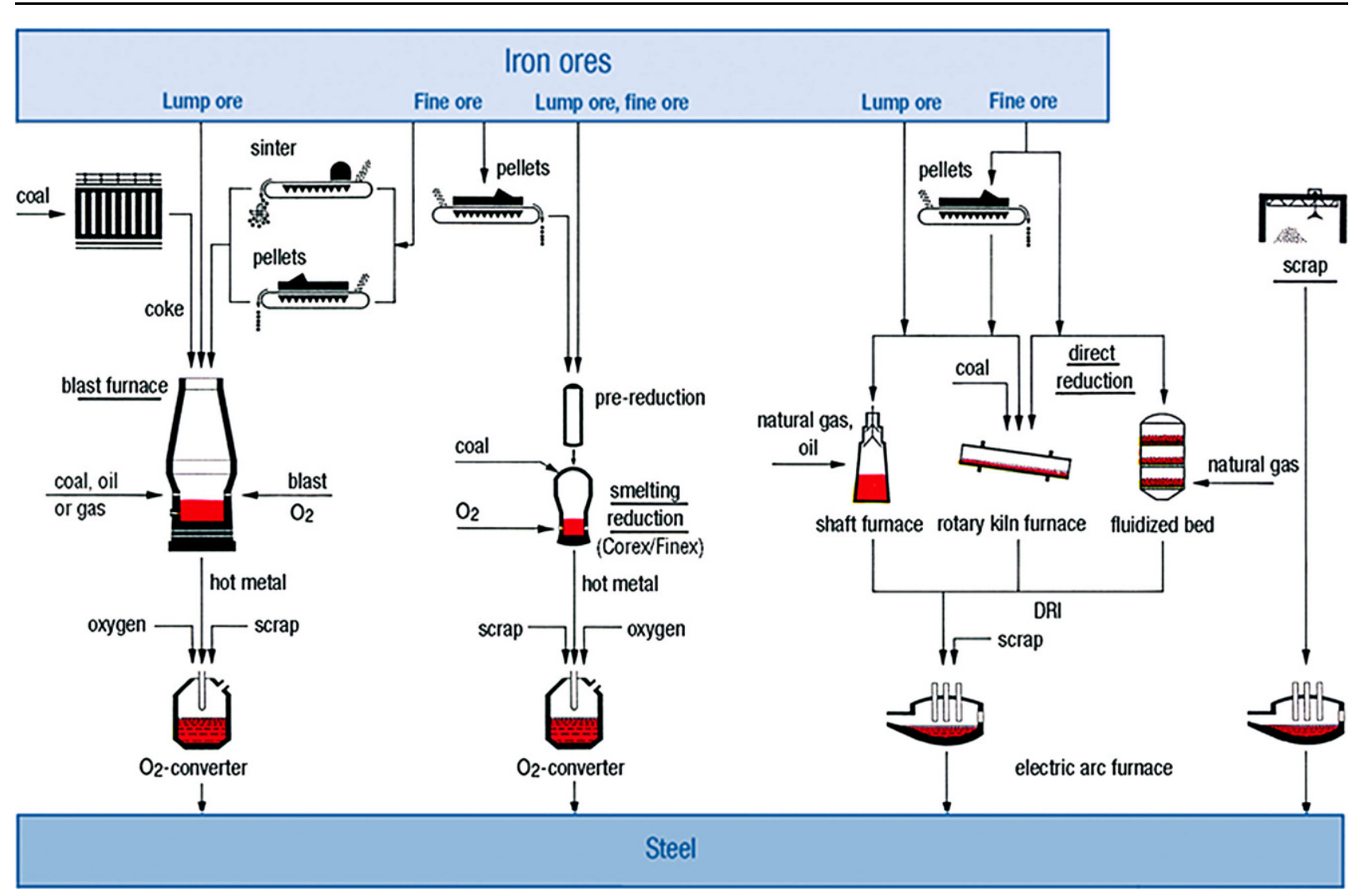

Fig. 1: Overview of steel production routes [2]

The production of steel from iron ore is highly reliant on carbon. Consequentially, $\mathrm{CO}_{2}$ is generated within the steel making process resulting in $1718 \mathrm{~kg} \mathrm{CO} 2$ per ton of crude steel. In 2016, the steel production accounts for $5 \%$ of all $\mathrm{CO}_{2}$ emissions across EU28 $[2,3]$.

\section{Strategy of EU Commission for Reduction of GHG Emission}

The EU, which accounts for $10 \%$ of global GHG emissions, intends to become climate-neutral by 2050. In 2009 the EU declared an 80-90\% reduction of its emissions by 2050. Recent decades have successfully demonstrated that it is possible to increase the gross domestic product, while reducing energy consumption and GHG emissions. This indicates the feasibility of decoupling these emissions from the economic growth. In 2018 the EU commission defined a vision and long-term strategy for a modern, competitive, prosperous, and climate neutral economy. The foundation for joint actions are provided by the following seven main strategic building blocks [4]:

- Maximise the benefits from energy efficiency including zero emission buildings

- Maximise the deployment of renewables and the use of electricity to fully decarbonise Europe's energy supply

- Embrace clean, safe and connected mobility
- A competitive EU industry and the circular economy as a key enabler to reduce $\mathrm{GHG}$ emissions

- Develop an adequate smart network infrastructure and inter-connections (sector coupling)

- Reap the full benefits of bio-economy and create essential carbon sinks

- Tackle remaining $\mathrm{CO}_{2}$ emissions with carbon capture and storage

\section{Challenges of EU Steel Industry to Reduce Carbon Intensity}

A substitution of the BF/BOF route through the scrap based EAF route leads to a possible $\mathrm{CO}_{2}$ mitigation of about $25 \%$ per ton of steel depending on the energy mix applied. Although the emissions of this route are likely to be further diminished by steadily increasing electrical energy production from renewable energy, the application of this route is limited in terms of availability and quality of scrap. Another alternative is direct reduction, whereby coal is replaced by natural gas as an energy source and reducing agent. This process generates direct reduced iron (DRI), which is subsequently melted to crude steel in the EAF. The reduction potential in comparison to the BF/BOF route is about $35 \%$ [5]. Hot metal production with smelting reduction technologies is based on coal, and, unless combined with Carbon Capture and Usage ( $\mathrm{CCU}$ ) technologies, the $\mathrm{CO}_{2}$ emission 
Fig. 2: Schematic view of two different PI mitigation technologies [8]

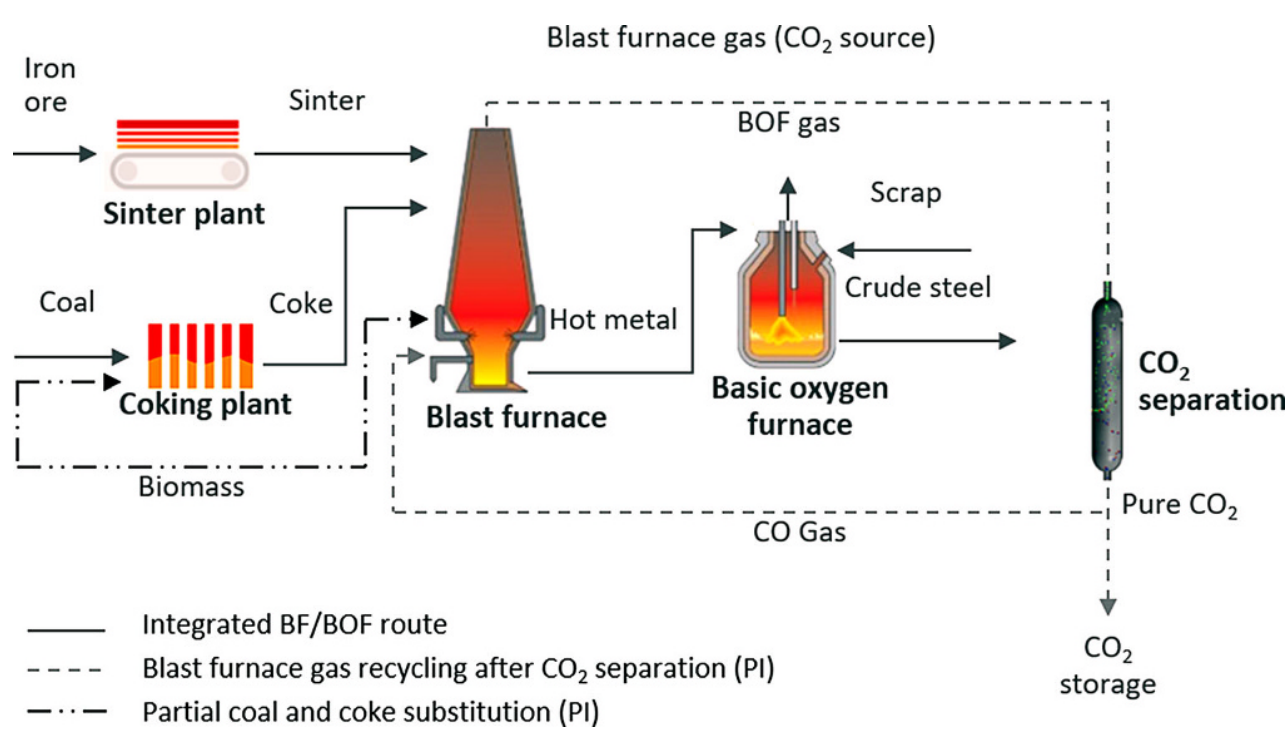

Blast furnace gas $\left(\mathrm{CO}_{2}\right.$ source $)$

cannot be reduced significantly in comparison to the BF including sintering and cokemaking.

Another opportunity for anthropogenic $\mathrm{CO}_{2}$ mitigation is the utilisation of solid biomass within metallurgical processes, whereby additional treatment steps (e.g. torrefication, pyrolysis) are required. A challenge is the availability of biomass in EU27, since the demand for biomass in other industrial sectors (pulp and paper, natural fibres, or chemicals) will increase within the next decades. A complete substitution of coal in the BF/BOF route with biomass is not possible [6].

Process optimisations and breakthrough technologies will inevitably be required and may be associated with large infrastructure costs. This would likely induce an increased price of produced steel having a negative impact on the competitiveness of the European steel industry. A transition towards a $\mathrm{CO}_{2}$ lean steel production is directly proportional to a higher consumption of electrical energy and will entail significant modifications regarding the production and distribution of energy. The decarbonisation of the energy sector is therefore one of the prerequisites for reducing GHG emissions from steel production, and the availability of renewable energy must be ensured. The conversion will have to take place in parallel with regular production and must neither affect standard operation nor the quality of the product [7].

\section{Initiative of EU Steel Industry Regarding $\mathrm{CO}_{2}$ Mitigation}

The EU steel industry is urged to improve its processes and develop innovative approaches to reduce its $\mathrm{CO}_{2}$ emissions. Therefore, the European steel producers have launched various projects for $\mathrm{CO}_{2}$ mitigation focusing on the technological pathways SCU and CDA. SCU includes the pathways Process Integration (PI) and CCU. At this point, it must be mentioned that, within the RFCS projects LowCarbonFuture and GREENSTEEL, various mitigation technologies are evaluated, obstacles are identified, and necessary framework conditions as well as possible approaches for a successful transition are developed [8].

\subsection{Process Integration (PI)}

$\mathrm{PI}$ aims at reducing the carbon input and the resulting $\mathrm{CO}_{2}$ emissions by adjusting existing iron and steel production processes (Fig. 2). Options are, among others, the recycling or increased utilization of steel plant gases (e.g. recycling of BF top gas as an auxiliary reducing agent), the partial replacement of coal by either natural gas or biomass, the increase of scrap/hot metal ratio, and the replacement of iron ore by hot briquetted iron ( $\mathrm{HBI}$ ). $\mathrm{PI}$ may also include the opportunity of final storage of captured carbon (CCS). Individual options can be combined to achieve the highest possible $\mathrm{CO}_{2}$ mitigation. The most suitable configuration for individual plants is determined by local specifications and framework conditions.

In the course of the ULCOS project, a joint research activity of the EU steel industry, two technologies have been developed for hot metal production with CCS. Both, the oxygen blast furnace and the smelting reduction technology HIsarna, were operated in pilot scale. Yet, an industrial realisation with sequestration of $\mathrm{CO}_{2}$ in a geological storage has not been realized so far [9].

\subsection{Carbon Capture and Usage (CCU)}

The aim of $\mathrm{CCU}$ is to bond $\mathrm{CO}_{2}$ originated from steel process chemicals e.g. via catalytic conversion processes. Fig. 3 shows an overview of possible products generated form $\mathrm{CO}_{2}$ and their current state of development.

The production of various $\mathrm{CO}_{2}$ based products requires hydrogen, whereas for $\mathrm{CO}_{2}$ lean $\mathrm{H}_{2}$-production, the availability of renewable energies and their volatility are important factors. It is important to note that $\mathrm{CCU}$ products should keep the containing $\mathrm{CO}_{2}$ for as long as possible [11]. and waste gases and to use the carbon for producing base 


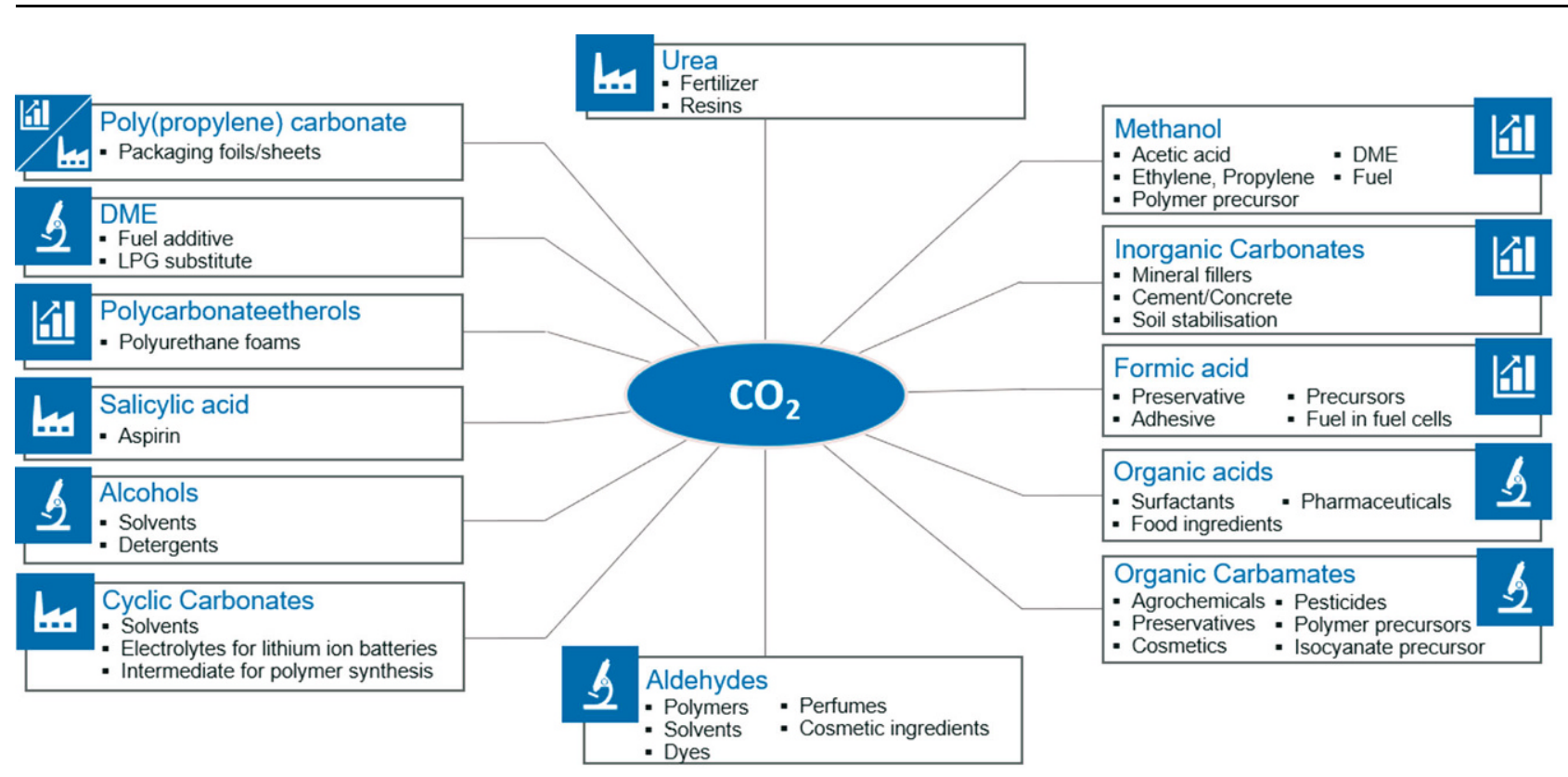

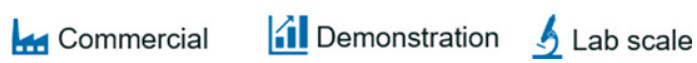

Fig. 3: Overview of possible $\mathrm{CO}_{2}$ utilization products and their current state of development [10]

$\mathrm{CO}_{2}$ is emitted at multiple stages during the steel production process. Therefore capturing, separating, and purifying it is an important aspect of CCU [7].

The German project Carbon2Chem aims at utilising $\mathrm{CO}_{2}$ from steel exhaust gases, which will be converted with hydrogen produced from renewable energies to ammonia or fuel. The project deals with the topics water, sustainable methanol production, gas cleaning/catalysis as well as production of polyalcohols, polymers, and oxymethylene ether (OME) [12].

Further technology developments taking place in Europe, which are also focusing on the production of chemicals with $\mathrm{CO}_{2}$ from steel plant gases, are the projects FReSMe and Steelanol $[13,14]$.

\subsection{Carbon Direct Avoidance (CDA)}

The CDA pathway is primarily dedicated to the development of new processes and technologies that allow the production of steel from virgin ores without a direct release of carbon emissions. These technologies use renewable electricity and/or hydrogen derived from renewable electricity.

The production of hydrogen in the environment of an integrated steel plant is in the focus of the European research project H2Future funded by the Fuel Cell and Hydrogen Joint Undertaking ( $\mathrm{FCH} J U$ ). At the site of voestalpine in Linz (Austria), the world's biggest proton exchange membrane (PEM) electrolyser with a power of $6 \mathrm{MW}$ has been installed [15].

With hydrogen in ionized state (plasma), steel can be produced from iron ore in a single process step (hydrogen plasma smelting reduction). An Austrian consortium is investigating this technological concept within the project
SuSteel. For the industrial application of this technology, further upscaling steps towards a pilot and demonstration scale are still required.

A Swedish project consortium is currently developing the HYBRIT technology, where hydrogen is used in molecular state as a reduction agent (Fig. 4). It aims at a $\mathrm{CO}_{2}$ free steel production comprising $\mathrm{CO}_{2}$ free pelletizing, production of DRI with hydrogen in a shaft furnace and further melting it in the EAF. A demonstration plant from 2025 onward should provide the foundation to shift the entire crude steel production in Sweden to this technology after 2035 [17].

A similar approach is applied within the German project SALCOS led by Salzgitter. An industry-scale modular concept should be developed for a stepwise transformation of $\mathrm{BF} / \mathrm{BOF}$ steel mills to a site with a direct reduction plant operated with $\mathrm{H}_{2}$ (incl. production and supply) and an EAF for melting [18].

Renewable electricity can also be directly used to reduce iron ore (electrolysis of iron ore). The high and low temperature electrolyses of iron ore are parts of currently ongoing research. The process developments started in the course of the ULCOS project, and the low temperature electrolysis will be further explored within the project SIDERWIN. These technologies require some additional upscaling steps in the next years to reach industrial maturity [19].

\section{Conclusions}

The climate targets of the EU and their fulfillment by 2050 will result in major changes, which are accompanied by technical, political and social challenges for the European steel industry. 
Fig. 4: Schematic view of hydrogen direct reduction [16]

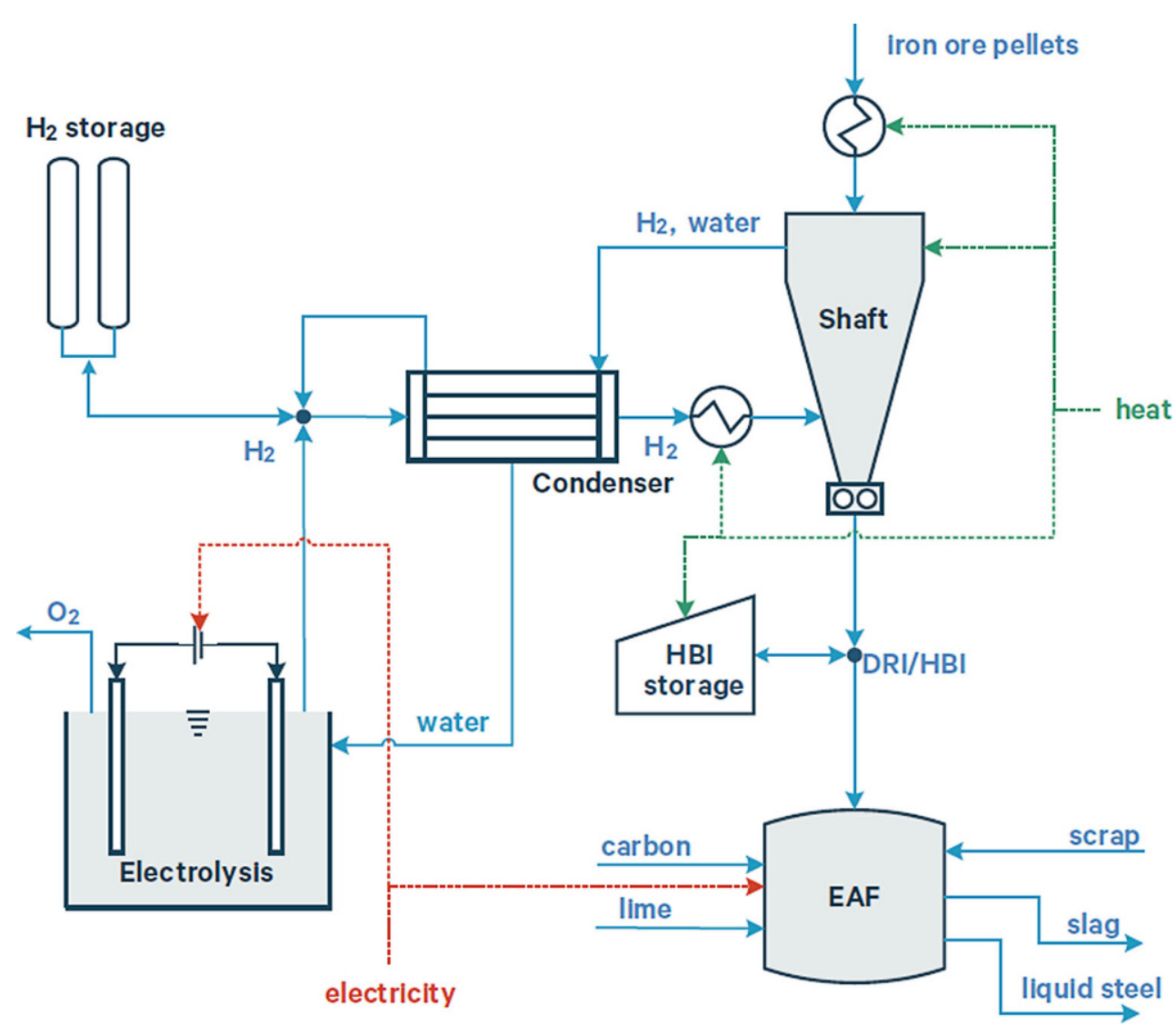

A secure and healthy industrial base in the EU, careful handling of EU imports and fair trade need to be ensured to prevent a possible delocalisation of steel production to non-European countries (carbon leakage) and negative effects on European competitiveness. The conversion towards a $\mathrm{CO}_{2}$ lean steel production requires a detailed evaluation and analysis of the various mitigation technologies and their integration into existing plants. The development of different mitigation technologies is affected by local circumstances and boundary conditions, and it is highly probable that different technologies evolve in parallel resulting in a diverse industrial environment. The different technologies should be implemented by plannable, smart, and affordable steps and several kinds of bridge technologies will probably be necessary.

An essential prerequisite for the implementation of decarbonisation technologies, whether they rely on electricity, hydrogen, or other renewable sources, is the availability of low carbon energy. Finally, an industrial symbiosis, i.e. sector coupling, must be considered, since the exchange of energy and material streams (by-product from one process as secondary raw material for another sector) will help to reduce the demand of primary resources and will contribute to an increased circular economy.

Acknowledgements. The authors gratefully acknowledge the funding support of K1-MET GmbH, metallurgical competence center. The research program of the K1-MET competence center is supported by COMET (Competence Center for Excellent Technologies), the Austrian program for competence centers. K1-MET is funded by the Federal Ministry for Transport, Innovation and Technology, the
Federal Ministry for Digital and Economic Affairs, the provinces of Upper Austria, Tyrol and Styria as well as the Styrian Business Promotion Agency (SFG).

Funding. Open access funding provided by Montanuniversität Leoben.

Open Access This article is licensed under a Creative Commons Attribution 4.0 International License, which permits use, sharing, adaptation, distribution and reproduction in any medium or format, as long as you give appropriate credit to the original author(s) and the source, provide a link to the Creative Commons licence, and indicate if changes were made. The images or other third party material in this article are included in the article's Creative Commons licence, unless indicated otherwise in a credit line to the material. If material is not included in the article's Creative Commons licence and your intended use is not permitted by statutory regulation or exceeds the permitted use, you will need to obtain permission directly from the copyright holder. To view a copy of this licence, visit http://creativecommons.org/licenses/by/4.0/.

\section{References}

1. The European Steel Association (2018): European Steel in Figures 2018, www.eurofer.org/News\%26Events/PublicationsLinksList/ 201806-SteelFigures.pdf (17.02.2020)

2. Die Wirtschaftvereinigung Stahl: Roheisen- und Rohstahlerzeugung, www.stahl-online.de (28.11.2019)

3. Mandova, H.; Patrizio, P.; Leduc, S.; Kjärstad, J.; Wang, C.; Wetterlund, E.; Kraxner, F.; Gale, W.: Achieving carbon-neutral iron and steelmaking in Europe through the deployment of bioenergy with carbon capture and storage, Journal of Cleaner Production, 218 (2019), pp 118-129

4. European Commission: A Clean Planet for all A European strategic long-term vision for a prosperous, modern, competitive and cli- 
mate neutral economy, https://eur-lex.europa.eu/legal-content/EN/ TXT/HTML/?uri=CELEX:52018DC0773\&from=EN (27.02.2020)

5. Schenk, J.; Lüngen, H.-B.: Evaluation of the capabilities of direct and smelting reduction process to enhance energy efficiency and to reduce $\mathrm{CO}_{2}$ emission of the steel production in Europe, in: 7th European Coke and Ironmaking Congress-ECIC, Linz, Austria, 2016, pp 13-23

6. Mousa, E.; Wang, C.; Riesbeck, J.; Larsson, M.: Biomass applications in iron and steel industry: An overview of challenges and opportunities, Renewable and Sustainable Energy Reviews, 65 (2016), pp 1247-1266

7. Wyns, T.; Khandekar, G.; Robson, I.: Institute for European Studies: Industrial Value Chain: A Bridge Towards a Carbon Neutral Europe, www.ies.be/files/Industrial_Value_Chain_25sept.pdf (24.02.2020)

8. RINA Consulting (2019) Low carbon future, www.lowcarbonfuture. eu (28.11.2019)

9. Quader, M.A.; Ahmed, S.; Ghazilla, R.A.R.; Ahmed, S.; Dahari, M.: A comprehensive review on energy efficient $\mathrm{CO}_{2}$ breakthrough technologies for sustainable green iron and steel manufacturing, Renewable and Sustainable Energy Reviews, 50 (2015), pp 594-614

10. Bazzanella, A. M.; Ausfelder, F.; DECHEMA e.V. (ed.): Technology Study: Low carbon energy and feedstock for the European chemical industry, Germany, 2017

11. Chan, Y.; Petithuguenin, L.; Fleiter, T.; Herbst, A.; Arens, M.; Stevenson, P.: Industrial Innovation: Pathways to deep decarbonisation of
Industry. Part 1: Technology Analysis, https://ec.europa.eu/clima/ sites/clima/files/strategies/2050/docs/industrial_innovation_part_1_ en.pdf (27.02.2020)

12. Deerber, G.; Oles, M.; Schlögl, R.: $\mathrm{CO}_{2}$-Reduzierung durch crossindustrielle Kooperation der Stahl-, Chemie- und Energiebranche, www.umsicht.fraunhofer.de/content/dam/umsicht/de/dokumente/ strategische-forschungslinien/kohlenstoffkreislauf/verbundprojektkohlenstoffkreislauf-carbon2chem.pdf (19.02.2020)

13. Steelanol (2020) Homepage, www.steelanol.eu/en (19.02.2020)

14. FReSME (2020) Homepage, www.fresme.eu/ (19.02.2020)

15. H2FUTURE (2019) Homepage, www.h2future-project.eu (28.11.2019)

16. Ahman, M.; Olsson, O.; Vogl, V.; Nyqvist, B.; Maltais, A.; Nolsson, L.J.; Hallding, K.; Skanberg, K.; Nolsson, M.: Stockholm Environment Institute (ed.): Hydrogen steelmaking for a low-carbon economy: A joint LU-SEI working paper for the HYBRIT project, Sweden, 2018

17. HYBRIT (2019) Homepage, www.hybritdevelopment.com (28.11.2019)

18. Salcos (2019) Homepage, salcos.salzgitter-ag.com/en/index.html? no_cache $=1(28.11 .2019)$

19. Siderwin (2019) Homepage, www.siderwin-spire.eu/ (19.02.2020)

Publisher's Note. Springer Nature remains neutral with regard to jurisdictional claims in published maps and institutional affiliations. 